\title{
FLAGRANTES DA PRESENÇA DE DANTE EM MACHADO DE ASSIS
}

\section{TERESINHA VÂNIA ZIMBRÃO DA SILVA}

Universidade Federal de Juiz de Fora

Juiz de Fora, Minas Gerais, Brasil

\section{IZABELLA MADDALENO}

Universidade Federal de Juiz de Fora

Juiz de Fora, Minas Gerais, Brasil

Resumo: Este artigo é um recorte de um trabalho maior que se propõe analisar as referências de Machado de Assis ao autor italiano Dante Alighieri e à sua obra. No presente texto, analisamos, sobretudo, as referências a Dante presentes nos romances Dom Casmurro e Memorial de Aires. Revisitamos a fortuna crítica desses livros, acrescentando então algumas considerações. Esperamos que esses flagrantes da presença de Dante em Machado de Assis sejam relevantes para os estudos machadianos.

Palavras-chave: Machado de Assis; Dante Alighieri; Dom Casmurro; Memorial de Aires.

\section{FLAGRANTS OF DANTE'S PRESENCE IN MACHADO DE ASSIS}

\begin{abstract}
This article is an excerpt from a larger work that aims to analyse Machado de Assis' references to Italian author Dante Alighieri and his work. In this article, we analyse, above all, the references to Dante present in the novels Dom Casmurro and Memorial de Aires. We revisit the critical fortune of these novels, adding to it some considerations. We hope that these flagrants of Dante's presence in Machado de Assis are relevant to Machadian studies.
\end{abstract}

Keywords: Machado de Assis; Dante Alighieri; Dom Casmurro; Memorial de Aires.

\section{Introdução}

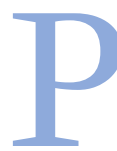
rincipiemos por notar que a presença de Dante na obra de Machado é deveras significativa e carece de ser melhor analisada pela fortuna crítica. A primeira pesquisa relevante sobre a referência dantesca na obra machadiana foi feita pelo italiano Edoardo Bizarri, que desenvolveu o tema em Machado de Assis e a Itália (1961) e também no artigo "Machado de 
Assis e Dante" (1965). Bizarri fez um exaustivo levantamento das citações diretas de versos dantescos referenciados na obra do escritor brasileiro, além de pontuar, ainda, algumas referências diretas a Dante e/ou à Divina comédia, sem citação de versos.

Um outro pesquisador que também desenvolveu o tema foi o francês Jean-Michel Massa, no artigo escrito em 1965, "A presença de Dante na obra de Machado de Assis" (2015), e no estudo de 1970, Machado de Assis tradutor (2008). Massa fez considerações produtivas acerca da presença de Dante em Machado sem, contudo, realizar acréscimos quantitativos às citações inventariadas por Bizarri.

Quatro décadas depois dessas pesquisas, surgiu o trabalho de Eugênio Vinci de Moraes: A Tijuca e o pântano. A divina comédia na obra de Machado de Assis entre 1870 e 1881 (2007). O pesquisador revisou o levantamento quantitativo de Edoardo Bizarri, acrescentando uma citação direta de verso dantesco que escapou ao trabalho exaustivo realizado pelo italiano em 19611965. A preocupação maior de Bizarri foi levantar as citações, já Moraes se dedicou a interpretar algumas.

Cabe acrescentar que, no horizonte da fortuna crítica machadiana das últimas décadas, além do trabalho de Moraes, surgiram outros estudos interpretando as citações de Dante levantadas por Bizarri desde 1961-1965, tais como os artigos "Uma página dantesca de Machado de Assis", de Osvaldo Ceschin (1999); "Machado de Assis: Dico, che quando l'anima mal nata", de Teresinha V. Zimbrão da Silva (2015); e "Machado de Assis e $A$ divina comédia", de Izabella Maddaleno e Teresinha V. Zimbrão da Silva (2019). ${ }^{1}$ Acrescenta-se também que os romances Helena, Memórias póstumas de Brás Cubas e Esaú e Jacó, o conto "O Alienista" e o poema "Niâni" apresentam, todos, citações de versos dantescos que já foram analisadas pela fortuna crítica machadiana.

Dadas essas considerações iniciais, este artigo se propõe a dar uma contribuição aos estudos sobre a presença de Dante em Machado de Assis. Considerando que, dentre os romances machadianos com citações diretas de versos dantescos, já foram estudados, da chamada fase da maturidade do escritor, Memórias póstumas de Brás Cubas por Moraes (2007) e por Ceschin (1999), Esaú e Jacó por Silva (2015) e por Maddaleno e Silva (2019), pretendemos contribuir para a pesquisa sobre a presença de Dante em

\footnotetext{
${ }^{1}$ Esse artigo de 2019, publicado pela revista Machado de Assis em Linha, detalha de modo didático e crítico o levantamento feito por Bizarri em 1961-1965 das citações machadianas de versos dantescos.
} 
Machado de Assis com o estudo dos romances da maturidade restantes, ou seja, Dom Casmurro e Memorial de Aires.

\section{Dom Casmurro e Memorial de Aires: traição e não confiabilidade do narrador}

O presente estudo sobre Dom Casmurro dialoga com os trabalhos de Helen Caldwell (1960), Silviano Santiago (1978), John Gledson (1984), Roberto Schwarz (1990) e (1997), Valentim Facioli (2008) e Alfredo Bosi (1999). Já o presente estudo sobre Memorial de Aires estabelece diálogo com os trabalhos de John Gledson (1986), Cilene Margarete Pereira (2007), Luiza Franco Moreira (2009), Pedro Fragelli (2014), Teresinha Zimbrão da Silva (2015), Izabella Maddaleno e Teresinha Zimbrão da Silva (2019).

Todos esses trabalhos mencionados têm em comum a defesa da não confiabilidade do narrador machadiano, seja este o advogado e ex-seminarista Bento Santiago, narrador de Dom Casmurro, seja o conselheiro e diplomata aposentado Aires, narrador do Memorial de Aires (e de Esaú e Jacó).

$O$ presente estudo também dialoga com o trabalho "Sobre $A$ divina comédia", prefácio de Otto Maria Carpeaux (2010) à obra dantesca. Desse trabalho, importa sobretudo destacar a afirmação de Carpeaux sobre a subjetividade da narração dantesca: " $A$ divina comédia [...] não é uma narração objetiva: no centro do poema não se encontra um personagem principal, mas o próprio poeta, que fala, durante a obra toda, em seu próprio nome, manifestando seus pensamentos, seus sentimentos, seus sofrimentos" (CARPEAUX, 2010, p. 8).

Notemos que Silva (2015) e Maddaleno e Silva (2019), ao estudarem a presença dantesca em Esaú e Jacó, sugerem que a obra do poeta possibilita a leitura do autoelogio e da vingança, pois Dante se coloca n' $A$ divina comédia ascendendo ao Paraíso, enquanto seus inimigos padecem os castigos do Inferno. É o que de certo modo já havia notado Carpeaux: "Mas em Dante [...] havia algo de fúria vingativa dos demônios e o poeta parece ter sentido uma simpatia secreta com os diabos que castigavam no inferno seus inimigos" (CARPEAUX, 2010, p. 11).

Pois, a partir das referências dantescas presentes em Dom Casmurro e no Memorial de Aires, dialogamos com esses trabalhos da crítica machadiana acrescentando algumas considerações, como vamos expor adiante, sobretudo no que diz respeito à temática da traição deveras relevante em Dom Casmurro, no Memorial de Aires, e também n' $A$ divina comédia.

De fato, além da não confiabilidade do narrador, o tema da traição comparece nessas obras. Em Dom Casmurro, o narrador advogado Bento não 
é confiável, porque tenta convencer o leitor da traição da esposa Capitu sem apresentar provas e, em Memorial de Aires, o narrador diplomata Aires também não é confiável, pois distrai o leitor e atenua com diplomacia a traição praticada pelo jovem casal Tristão e Fidélia ao abandonar o Brasil e ir para Portugal. Notemos ainda que esse narrador não confiável também trai o leitor, seja tentando convencê-lo da traição de Capitu, no caso de Casmurro, seja atenuando a traição dos namorados Tristão e Fidélia, no caso de Aires.

$\mathrm{O}$ tema da traição também é fundamental $\mathrm{n}^{\prime} A$ divina comédia. Lembremos que a traição amorosa é punida como luxúria no segundo círculo do Inferno e no sétimo círculo do Purgatório. Já a traição ao próximo, o pior de todos os pecados segundo a doutrina cristã, é punida no nono e último círculo infernal. Lá é o local onde as almas recebem o maior castigo de todo o Inferno, e é onde está o traidor-mor Judas Iscariote, que traiu seu mestre e benfeitor Jesus Cristo.

Lembremos que Dante coloca seus inimigos sendo punidos no Inferno, muitos deles por traição. Nessa linha de leitura, o poeta seria um narrador que tenta convencer o seu leitor do quanto ele é um bom cristão, "destinado à ventura de ser salvo e ascender ao Paraíso" (SILVA, 2015, p. 328), enquanto que seus inimigos seriam, ao contrário, diabólicos e maus cristãos, destinados a penar nos círculos infernais.

Quanto a Machado de Assis, procuraremos mostrar que a presença de Dante nos seus dois romances - tanto nas citações diretas de versos dantescos como nas referências dantescas sem versos - complementa o diálogo do escritor com a temática da traição, a saber: seja amorosa em Dom Casmurro, seja da traição ao próximo em Memorial de Aires.

\section{Dom Casmurro e a presença de Dante}

Em Dom Casmurro, romance publicado em 1899, Machado cita os versos 142 e 143 do canto XXXIII do Purgatório de Dante levantados por Bizarri (1961), além de fazer uma referência dantesca sem citação de verso, levantada pelo presente artigo. Eis o quadro I a respeito disso:

\begin{tabular}{|l|l|}
\hline Dom Casmurro & $\begin{array}{l}\text { Versos d'A divina comédia } \\
\text { (ALIGHIERI, 2010) }\end{array}$ \\
\hline Capítulo CXXIX & \\
$\begin{array}{l}\text { Um dia, iremos daqui até a porta do Céu, } \\
\text { onde nos encontraremos renovados, como as }\end{array}$ & $\begin{array}{l}\text { rifatto sí come piante novelle / } \\
\text { rinovellate di novella fronda. }\end{array}$ \\
\hline
\end{tabular}




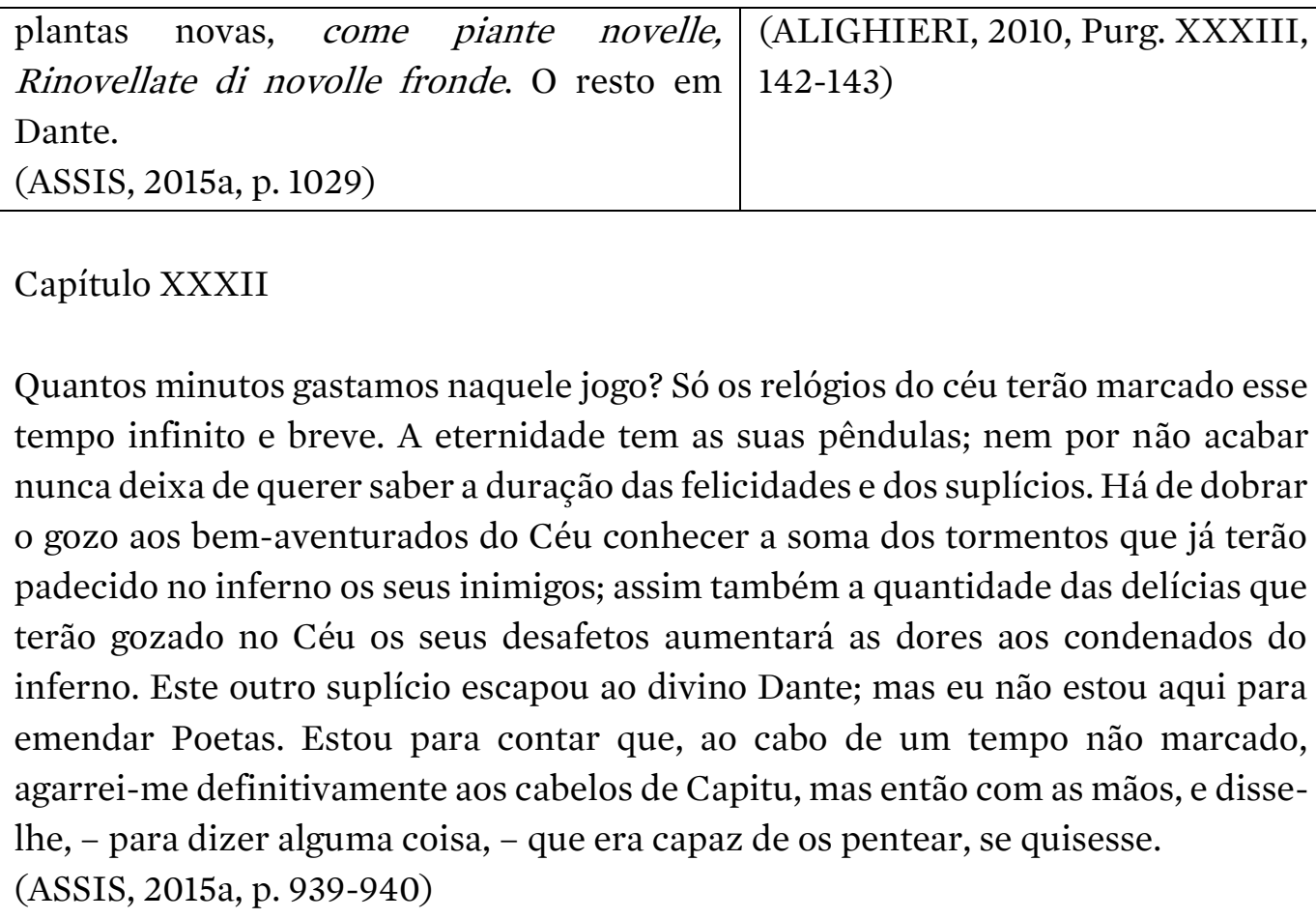

Quantos minutos gastamos naquele jogo? Só os relógios do céu terão marcado esse tempo infinito e breve. A eternidade tem as suas pêndulas; nem por não acabar nunca deixa de querer saber a duração das felicidades e dos suplícios. Há de dobrar o gozo aos bem-aventurados do Céu conhecer a soma dos tormentos que já terão padecido no inferno os seus inimigos; assim também a quantidade das delícias que terão gozado no Céu os seus desafetos aumentará as dores aos condenados do inferno. Este outro suplício escapou ao divino Dante; mas eu não estou aqui para emendar Poetas. Estou para contar que, ao cabo de um tempo não marcado, agarrei-me definitivamente aos cabelos de Capitu, mas então com as mãos, e disselhe, - para dizer alguma coisa, - que era capaz de os pentear, se quisesse.

(ASSIS, 2015a, p. 939-940)

Como já mencionamos, nesse romance, o narrador, advogado e exseminarista Bento Santiago não é confiável porque, ao narrar suas memórias, tenta convencer o leitor da traição da esposa Capitu sem apresentar de fato provas. É o que, de um modo geral, defendem os críticos do romance com os quais estamos dialogando: Helen Caldwell (1960), Silviano Santiago (1978), John Gledson (1984), Roberto Schwarz (1990) e (1997), Valentim Facioli (2008) e Alfredo Bosi (1999).

A presença efetiva de Dante em Dom Casmurro, através da citação direta de um verso do Purgatório e da referência dantesca sem verso expostas no quadro I, nos motiva a testar o alcance dessa presença ao longo do romance. $\mathrm{N}^{\prime} A$ divina comédia, Dante narra/canta uma viagem metafísica na qual percorreu o Inferno, o Purgatório e o Paraíso; em Dom Casmurro, Bento narra a viagem da sua vida física percorrendo a adolescência, a juventude e a maturidade. Na sua narrativa, em tempos religiosos de cristandade, Dante apresenta os seus inimigos como culpados de pecados capitais a penar no Inferno. Por sua vez, em tempos de realismo, Casmurro apresenta a sua esposa/inimiga como culpada do pecado de adultério.

É preciso notar que tanto Dante como Bento iniciam suas respectivas jornadas memorialísticas evocando uma atmosfera sombria. Ambos 
mencionam os termos "sombra" e "porta" no início da narração. Seja sombra e porta do Inferno em um (Inf. I, 1-21), seja sombra e porta relacionadas à casa materna em outro (ASSIS, 2015a, p. 907-908), o fato é que, em ambos, os termos sugerem a entrada por um caminho marcado por muitas incertezas, dores e sofrimentos.

Observemos que, n'A divina comédia, Dante narra que, apesar de ter se desviado da diritta via, não perdeu a sua fé e chegará ao final da sua jornada ao Paraíso. Pois Bento, ex-seminarista, sugere em sua narrativa que se desviou do justo caminho, perdeu a sua fé, e se tornou o Casmurro de "hábitos reclusos e calados" (ASSIS, 2015a, p. 907) que narra as suas memórias com o receio de ter, talvez, até vendido a alma ao Diabo como sugere a sua citação do Fausto de Goethe: "Aí vindes outra vez, inquietas sombras?" (ASSIS, 2015a, p. 907).

Ora, é esse Casmurro advogado e ex-seminarista que acusa Capitu de têlo seduzido e desviado do justo caminho do seminário, casando-se com ele, para depois de tudo traí-lo, e assim desviá-lo de vez da diritta via. No processo acusatório dele, a jovem é a responsável por tomar as iniciativas que os levaram ao namoro e depois ao casamento. Pois "Capitu era Capitu, isto é [...] mais mulher do que eu era homem" (ASSIS, 2015a, p. 937). A sabedoria e a inteligência dela, que tanto contribuíram para tirá-lo do seminário, serviriam, depois de casados, para enganá-lo numa traição com o seu melhor amigo Escobar.

Na narração de suas memórias, Bento insinua até que Capitu, com seus "olhos que o Diabo lhe deu [...] de cigana oblíqua e dissimulada" (ASSIS, 2015a, p. 931), é uma mulher diabólica, e que, portanto, usou dos poderes de sedução para desviá-lo do justo caminho. Se ele, ex-seminarista, vendeu de fato a sua alma ao Diabo tal como o Fausto de Goethe, ela seria a responsável por isso: uma cigana-bruxa adúltera digna de ser queimada no Inferno dantesco. A sua traição é que o teria desviado para as veredas do profano e do diabólico. Bento cobra a Capitu a pureza e a ingenuidade perdidas por Bentinho. Perdas que o tornaram o velho Casmurro sem alma: "falto eu mesmo" (ASSIS, 2015a, p. 907).

Ambos os personagens se descrevem a percorrer cada qual uma jornada que leva a caminhos bem diferentes; o de Dante é o da salvação no Paraíso guiado por Beatriz, e o de Bento é o da casmurrice solitária por culpa da diabólica Capitu. O primeiro eleva-se ao Paraíso, já o segundo se torna um velho casmurro que receia ter vendido a sua alma ao Diabo.

Se, na narração de Dante, Beatriz, a amada que o guia ao Paraíso, está próxima da sagrada Maria, mãe de Deus, para o narrador Bento, Capitu se aproxima da pecadora Eva, que, tentada pela serpente diabólica, seduziu e provocou a queda do homem do Paraíso. O amor de salvação, em um, se tornou 
o amor de perdição, no outro. A temática do amor platônico Dante/Beatriz desenvolvida n' $A$ divina comédia é atualizada em termos do amor "adúltero" Bento/Capitu em Dom Casmurro.

Quanto às referências dantescas, principiemos por notar que, ainda na juventude, Bento, depois de uma cena de ciúmes, se imaginou mastigando a "traidora" Capitu: "Duas vezes dei por mim mordendo os dentes como se a tivesse entre eles" (ASSIS, 2015a, p. 983). Estamos sugerindo que esta cena é uma possível referência dantesca: no nono círculo infernal, o Diabo mastiga e devora o traidor-mor Judas Iscariote como punição por trair ao próximo (Inf. XXXIV, 28-84). Estaria então sendo aplicada à suposta traição luxuriosa da personagem, que Dante puniria no segundo círculo, uma pena do nono círculo infernal. Na cena imaginada por Bento, a traição e punição de Capitu é aumentada em grau, e equipara-se à traição e punição de Judas Iscariote.

A punição real de Capitu, acusada de infidelidade sem provas, foi a de ser enviada por Casmurro para sofrer no exílio, vivendo solitária com seu filho em um país com língua e cultura diferentes. Notemos que o sofrimento causado pela acusação de traição e adultério está presente tanto nas personagens femininas de Dante, punidas no Inferno e no Purgatório, como nessa personagem machadiana de mais de quatro séculos depois. Todas são vítimas da ideologia patriarcalista que há mais de dois mil anos oprime e rebaixa o feminino.

Quanto ao verso do Purgatório dantesco citado em Dom Casmurro (ver quadro I), notemos que ele se refere no original à renovação das almas com o objetivo de alcançarem o Paraíso, recompensa para os virtuosos. No texto machadiano, Bento o cita para sugerir a possível renovação espiritual que aconteceria quando ele e Sancha, os "traídos" por Capitu e Escobar, se reencontrassem depois da morte à porta do céu. De onde se subentende que, à "traidora" e "diabólica" Capitu, caberia tão somente o Inferno.

Se compararmos a versão machadiana do verso, "renovados, come piante novelle, Rinovellate di novelle fronde" (ASSIS, 2015a, p. 1029), com o original, "rifatto si come piante novelle / rinnovellate di novella fronda" (Purg. XXXXIII, 142-143), na tradução para o português, ${ }^{2}$ "como de novas folhas, ao rompê-las / de sua ramagem, se renova a planta" (Purg. XXXXIII, 142-143), poderemos notar que uma modificação sobressai: o singular dantesco "novella fronda" torna-se o plural machadiano "novelle fronde", provavelmente, para concordar sintaticamente com a frase em português. Essa citação do

${ }^{2}$ Estamos utilizando a edição bilíngue de 2010, na tradução de Italo Eugenio Mauro, publicada pela Editora 34. 
Purgatório também comparece na crônica machadiana de 5 de julho de 1896 (referência dantesca levantada por Bizarri (1961)), na qual o cronista nos descreve um clube de música famoso na época, que acabou por ser fechado. A partir disso, ele reflete sobre a transitoriedade das coisas e estabelece uma relação entre a música, os versos de Dante e a sensação de ruínas: "Só a música pode dar a sensação destas ruínas. O verso também pode, mas há de ser pela toada do florentino, que assim como sabe a nota da maior dor, não menos conhece a da rejuvenescência, aquela que me faz crer, nestas sensações de arte". E logo em seguida cita: "Riffato si, come piante novelle / Rinnovelate di novella fronda..." (ASSIS, 2015d, p. 1209). Notemos que, se no romance, o verso comparece modificado, na crônica, é citado como no original.

Essa citação do verso dantesco, tanto na crônica como em Dom Casmurro, se refere à morte e também à possibilidade da rejuvenescência, apesar de tudo. Já a referência machadiana a Dante sem citação de verso (ver quadro I) é sobre a juventude e seus suplícios, sejam de dor ou mesmo de gozo, e se dá na cena em que os jovens Bento e Capitu estão diante um do outro, olhos nos olhos. O narrador sublinha então que o suplício dos inimigos no Inferno aumentaria o gozo dos bem-aventurados no Céu. Do mesmo modo que o gozo no Céu seria tormento aos inimigos que estão penando no Inferno. E conclui: "Este outro suplício escapou ao divino Dante; mas eu não estou aqui para emendar Poetas" (ASSIS, 2015a, p. 939-940).

Essa sugestão de um suplício que escapa ao próprio Dante também comparece na crônica de $1^{\mathrm{o}}$ de julho de 1876 (referência dantesca levantada pelo presente artigo): "Não aconteceu o mesmo àquele sujeito do Ceará, a quem quiseram dar a última casa, estando ele vivo, e mais que vivo. Um minuto mais, tinha ele cinco palmos de terra sobre o ventre, por outras palavras um suplício maior que o de todos os que inventou Dante" (ASSIS, 2015d, p. 279). E comparece ainda no Memorial de Aires, como voltaremos a ver adiante: "A reconciliação eterna, entre dois adversários eleitorais, devia ser exatamente um castigo infinito. Não conheço igual n' $A$ divina comédia. Deus, quando quer ser Dante, é maior que Dante" (ASSIS, 2015a, p. 1233). Como mencionamos, as referências dantescas na obra machadiana são muito recorrentes e, algumas, inclusive, se repetem, comparecendo em diferentes textos, como são o presente caso e o seguinte. 
Em Memorial de Aires, último romance publicado em 1908, pouco antes da sua morte, Machado cita o verso 93 do canto V do Inferno e o verso 133 do canto V do Purgatório, já levantados por Bizarri (1961), e faz uma referência sem citação de verso sobre $A$ divina comédia, registrada também por Bizarri (1965). Eis o quadro II a respeito disso:

\begin{tabular}{|c|c|c|}
\hline \multicolumn{2}{|c|}{ Memorial de Aires } & Versos d'A divina comédia \\
\hline $\begin{array}{l}11 \text { de fevereiro de } \\
1888\end{array}$ & $\begin{array}{l}\text { Verdade é que o nome da } \\
\text { família, que serve ao título } \\
\text { nobiliário, Santa-Pia, também } \\
\text { não o acho na lista dos } \\
\text { canonizados, e a única pessoa } \\
\text { que conheço assim chamada, é } \\
\text { a de Dante: Ricorditi di me, chi } \\
\text { son la Pia. } \\
\text { (ASSIS, 2015a, p. 1212) }\end{array}$ & $\begin{array}{l}\text { ricorditi di me, che son la } \\
\text { Pia. } \\
\text { (ALIGHIERI, 2010, Purg: V, } \\
\text { 133) }\end{array}$ \\
\hline $\begin{array}{l}1^{\circ} \text { de agosto de } \\
1888\end{array}$ & $\begin{array}{l}\text { A reconciliação eterna, entre } \\
\text { dois adversários eleitorais, } \\
\text { devia ser exatamente um } \\
\text { castigo infinito. Não conheço } \\
\text { igual na Divina Comédia. } \\
\text { Deus, quando quer ser Dante, } \\
\text { é maior que Dante. } \\
\text { (ASSIS, 2015a, p. 1233) }\end{array}$ & \\
\hline $\begin{array}{l}12 \text { de setembro de } \\
1888\end{array}$ & $\begin{array}{l}\text { Entrei nesta dúvida, - se } \\
\text { teriam estado juntos na rua ou } \\
\text { na loja a que ela veio, ou no } \\
\text { banco, ou no inferno, que } \\
\text { também é lugar de namorados, } \\
\text { é certo que de namorados } \\
\text { viciosos, del mal perverso. } \\
\text { (ASSIS, 2015a, p. 1246) }\end{array}$ & $\begin{array}{l}\text { [...] del nostro mal perverso. } \\
\text { (ALIGHIERI, 2010, Inf. V, } \\
\text { 93) }\end{array}$ \\
\hline
\end{tabular}

Como já mencionamos, nesse romance, o aposentado, conselheiro e diplomata Aires não é um narrador confiável, pois distrai o leitor e atenua com diplomacia a traição praticada pelo jovem casal Tristão e Fidélia ao abandonar o Brasil e ir para Portugal. É o que, de um modo geral, defendem os críticos do 
romance com os quais estamos dialogando: John Gledson (1986), Cilene Margarete Pereira (2007), Luiza Franco Moreira (2009), Pedro Fragelli (2014), Teresinha Zimbrão da Silva (2015) e Izabella Maddaleno e Teresinha Zimbrão da Silva (2019).

A presença efetiva de Dante em Memorial de Aires (ver quadro II), através da citação de dois versos, um do Inferno e outro do Purgatório, além da referência dantesca sem verso, nos motiva a testar o alcance dessa presença ao longo do romance. Principiemos por notar que o verso do Inferno citado em Memorial de Aires, "del mal perverso" (ASSIS, 2015a, p. 1246), está um pouco modificado, pois falta a palavra "nostro", presente no original, e se refere aos namorados viciosos Francesca e Paolo, condenados ao segundo círculo infernal, o da luxúria, por terem cometido traição e adultério. O casal dantesco é convocado pelo narrador Aires para insinuar o possível namoro de um outro casal, no caso não vicioso, pois se trata de uma viúva com nome sugestivo do oposto à traição: Fidélia.

Notemos que essa referência dantesca está sendo utilizada em contexto diverso ao original, tal como em Dom Casmurro, na cena em que o ciumento Bento se imaginou mastigando a "traidora" Capitu: mastigar e devorar o outro é uma punição dantesca aplicada à traição ao próximo e não à amorosa. Já mencionamos que o tema da traição em Memorial de Aires, tal como o estamos definindo, não diz respeito ao adultério, punido no segundo círculo infernal, e sim à traição ao próximo, punida no nono círculo infernal.

De fato, Tristão e Fidélia cometeram vários tipos de traição ao próximo, pertinentes de serem punidos no nono círculo do Inferno dantesco. Fidélia, contrariando a ideia de fidelidade contida em seu nome, traiu o pai, quando se casou com o inimigo da família dela; a pátria, ao ter ido embora do Brasil com a sua herança, deixando os escravos desamparados; os pais postiços e benfeitores, quando abandonou o casal Aguiar e Carmo, que a tinham como filha. Tristão, por sua vez, traiu duplamente a pátria e os pais postiços e benfeitores, seja quando foi embora pela primeira vez com a família, naturalizando-se português, seja quando partiu depois junto com Fidélia.

A outra referência dantesca, o verso do Purgatório citado em Memorial de Aires, "Ricorditi di me, chi son la Pia" (ASSIS, 2015a, p. 1212), na tradução para o português, "recorda-te de mim que sou a Pia" (Purg: V, 133), comparece no momento em que o narrador Aires questiona o título nobiliárquico do pai de Fidélia, ou seja, Barão de Santa Pia, recordando então a personagem de Dante Pia de Tolomei, que foi morta violentamente acusada de ter traído o marido, pecado do qual ela teria se arrependido antes de morrer e por isso 
mesmo conseguiu a graça de ir para o Purgatório, local onde ela, ao encontrar Dante, pede para ser lembrada no mundo terreno.

Pois os ex-escravos da fazenda de café Santa Pia também pediram a Fidélia que não os abandonasse, não os esquecesse, que se mantivesse fiel a eles. O pedido deles evoca o de Pia, que roga a Dante para ser lembrada no mundo dos vivos. Contudo, os "vínculos perpétuos e divinos" (ASSIS, 2015a, p. 1236) estabelecidos entre a jovem cativadora e os cativos não são suficientes para segurar Fidélia, que os abandona à própria sorte e parte rumo a Portugal.

Notemos que no conto machadiano "Uma por outra" (ASSIS, 2015b), Machado também faz referência a Pia de Tolomei (referência dantesca levantada pelo presente artigo), evidenciando uma personagem feminina que recebeu o nome Pia por ser piedosa: "Chamei-lhe Pia. Se me perguntares a razão deste nome, ficarás sem resposta; foi o primeiro que me lembrou, e talvez porque a Ristori representava então a Pia de Tolomei [...] atribuí naturalmente à desconhecida a piedade de uma grande alma" (ASSIS, 2015d, p. 279). Pois a Pia de Dante manifesta-se também piedosa, arrependendo-se da traição da qual foi acusada. Já Fidélia não demonstra nenhum arrependimento pela traição cometida ao fugir do seu país e deixar o casal Aguiar e Carmo, e ainda os ex-escravos, todos abandonados, revelando-se, ao contrário do que sugere o nome Pia da família e do que sugere o seu próprio nome Fidélia, de todo impiedosa e infiel para com eles.

Dante pune a traição ao próximo como sendo o pior dos pecados, contudo, em Memorial de Aires, a traição de Tristão e Fidélia fica encoberta pela narrativa diplomática de Aires. $\mathrm{O}$ casal não sofre nenhuma condenação ou punição por sua infidelidade, muito pelo contrário, eles têm o privilégio de viajar para outro país, ricos e bem-sucedidos, desfrutando assim de uma vida confortável na Europa sem demonstrar nenhum arrependimento ou piedade para com os que ficaram no Brasil.

Quanto à referência dantesca sem citação de verso, notemos que essa comparece em um comentário de Aires a respeito da rivalidade entre o pai de Fidélia, o Barão de Santa Pia, e o pai do marido dela: "A reconciliação eterna, entre dois adversários eleitorais, devia ser exatamente um castigo infinito. Não conheço igual em $A$ divina comédia. Deus, quando quer ser Dante, é maior que Dante" (ASSIS, 2015a, p. 1233). Já mencionamos que essa sugestão machadiana de um suplício que escapa ao próprio Dante comparece ainda, como vimos, em Dom Casmurro e na crônica de $1^{\circ}$ de julho de 1876, ou seja, em pelo menos três textos machadianos, comprovando a recorrência da presença de Dante na obra de Machado de Assis. 


\section{Considerações finais}

Machado de Assis afirma não querer "emendar poetas", no entanto, como esperamos ter demonstrado, emenda suplícios aos inventados por Dante em Dom Casmurro e no Memorial de Aires. A sua afirmação soa então como uma ironia, pois faz exatamente o contrário: está ali emendando poetas e, no caso estudado, é Dante Alighieri quem comparece referenciado, ora semelhante, ora dessemelhante ao original. De fato, a partir do estudo das referências dantescas, ou seja, as emendas machadianas ao poeta Dante, acrescentamos algumas considerações aos trabalhos anteriores da crítica machadiana sobre os romances Dom Casmurro e Memorial de Aires. Esperamos que esses acréscimos, ou flagrantes, tenham a sua relevância e possam contribuir para os estudos sobre a presença de Dante em Machado de Assis.

\section{Referências}

ALIGHIERI, Dante. A divina comédia. Edição bilíngue. Tradução Italo Eugenio Mauro. Prefácio de Otto Maria Carpeaux. São Paulo: Editora 34, 2010. 3 v.

ASSIS, J. M. Machado de. Obra Completa. 3 ed. São Paulo: Nova Aguilar, 2015a. v. 1. Obra Completa. 3 ed. São Paulo: Nova Aguilar, 2015b. v. 2.

Obra Completa. 3 ed. São Paulo: Nova Aguilar, 2015c. v. 3.

Obra Completa. 3 ed. São Paulo: Nova Aguilar, 2015d. v. 4.

BIZARRI, Edoardo. Machado de Assis e a Itália. Caderno do Instituto Cultural ÍtaloBrasileiro, São Paulo, n. 1, 1961.

. Machado de Assis e Dante. Caderno do Instituto Cultural Ítalo-Brasileiro, O meu Dante, São Paulo, n. 5, p. 133-144, 1965.

BOSI, Alfredo. Machado de Assis: o enigma do olhar. São Paulo: Ática, 1999.

CALDWELL, Helen. The Brazilian Othello of Machado de Assis. Berkeley: University of California Press, 1960.

CARPEAUX, Otto Maria. Sobre $A$ divina comédia. In: ALIGHIERI, Dante. $A$ divina comédia. Edição bilíngue. Trad. Italo Eugenio Mauro. São Paulo: Editora 34, 2010. v. 1, p. 7-18.

CESCHIN, Osvaldo Humberto Leonardi. Uma página dantesca de Machado de Assis. Revista do Instituto Italiano de Cultura, São Paulo, v. 8, p. 104-109, 1999.

FACIOLI, Valentim. Amor e bruxaria. Biblioteca Entrelivros, São Paulo, n. 10, p. 3641, 2008.

FRAGELLI, Pedro. As formas da traição: Machado de Assis, o Memorial de Aires e a abolição da escravatura no Brasil. São Paulo: Alameda, 2014.

GLEDSON, John. The Deceptive Realism of Machado de Assis. Liverpool: Francis Cairns, 1984. 
Machado de Assis: ficção e história. Rio de Janeiro: Paz e Terra, 1986.

MADDALENO, Izabella; SILVA, Teresinha V. Zimbrão da. Machado de Assis e $A$ divina comédia. Machado de Assis em Linha, São Paulo, v. 12, n. 26, p. 181-198, abr. 2019.

em:

<https://www.scielo.br/j/mael/a/phv3g5NR4tbnzWw8HjKXdwp/?lang=pt\&forma $\mathrm{t}=\mathrm{pdf}>$. Acesso em: 11 jun. 2021. doi:10.1590/1983-68212019122610.

MASSA, Jean-Michel. Machado de Assis tradutor. Tradução Oséias Silas Ferraz. Belo Horizonte: Crisálidas, 2008.

Presença de Dante na obra de Machado de Assis. Tradução Eugênio Vinci de Moraes; Maria Adriana Camargo Capello. Machado de Assis em Linha, São Paulo, v.

8, n. 16, p. 138-148, dez. 2015. Disponível em: <https://www.scielo.br/j/mael/a/tY5ssSLwWXFVv4Vpmsws8Ng/?lang=pthttp:// machadodeassis.fflch.usp.br>. Acesso em: 15 out. 2018. doi:10.1590/1983682120158168.

MORAES, Eugênio Vinci de. A Tijuca e o pântano. A divina comédia na obra de Machado de Assis entre 1870 e 1881. 2007. 179f. Tese (Doutorado em Literatura Brasileira) - Faculdade de Filosofia, Letras e Ciências Humanas, Universidade de São Paulo, São Paulo, 2007. Disponível em: $<$ https://teses.usp.br/teses/disponiveis/8/8149/tde-13022008-105611/pt-br.php>. Acesso em: 11 out. 2018.

MOREIRA, Luiza Franco. Sinceridade e descaso: meias verdades e duplo enredo em Memorial de Aires. Machado de Assis em Linha, São Paulo, n. 3, p. 53-62, jun. 2009 Disponível em: $<$ http://machadodeassis.net/download/numero03/num03artigo05.pdf $>$. Acesso em: 29 jan. 2019.

PEREIRA, Cilene Margarete. A assunção do papel social em Machado de Assis: uma leitura do Memorial de Aires. São Paulo: Annablume, Fapesp, 2007.

SANTIAGO, Silviano. Uma literatura nos trópicos: ensaios sobre dependência cultural. São Paulo: Perspectiva, 1978.

SCHWARZ, Roberto. Machado de Assis: um mestre na periferia do capitalismo. São Paulo: Duas Cidades, 1990.

Duas meninas. São Paulo: Companhia das Letras, 1997.

SILVA, Teresinha V. Zimbrão da. Machado de Assis: Dico, che quando l'anima mal nata. Revista Estação Literária, Londrina, v. 13, p. 324-334, jan. 2015. Disponível em: <http://www.uel.br/pos/letras/EL/vagao/EL13-Art22.pdf>. Acesso em: 11 jun. 2021. 
TERESINHA V. ZIMBRÃO DA SILVA é doutora em Literatura pela University of Newcastle Upon Tyne (1994), com pós-doutorado em Literatura pela PUC-Rio (2007). É Professora Titular da Graduação e da Pós-Graduação em Letras da Universidade Federal de Juiz de Fora. SobreMachado de Assis, publicou os artigos "Espiritualidade em Machado de Assis" (Graphos, 2017), "O sermão do diabo: uma irreverência machadiana" (Verbo de Minas, 2016), "Machado de Assis: Dico, che quando l'anima mal nata" (Estação Literária, 2014), "Machado de Assis e o mulato de 'alma grega'" (Machado de Assis em Linha, 2014), "Machado de Assis e A divina comédia" (Machado de Assis em Linha, 2019).

Orcid: http://orcid.org/0000-0002-9866-1151. E-mail: teresinha.zimbrao@gmail.com

IZABELLA MADDALENO é doutora em Letras pela Universidade Federal de Juiz de Fora com a tese "A apropriação machadiana de A divina comédia de Dante". Atuou ainda na mesma instituição como professora substituta de italiano. Publicou o artigo "Machado de Assis e A divina comédia" (Machado de Assis em linha, 2019).

Orcid: http://orcid.org/0000-0002-9719-4627 E-mail: izabellaletras@gmail.com

Recebido: 11.06.2021

Aprovado: 26.08.2021 